Ann. Biol, anim. Bioch. Biophys., I975, 15 (3), 54I-546.

\title{
ADIPOCYTE GROWTH OF FOUR ADIPOSE DEPOSITS IN RABBIT
}

\author{
J. NOUGUÉS \\ with the technical assistance of Odette Moulderac, Thérèse Chery and E. Bouthier \\ Station de Physiologic animale, I. N.R. A., \\ Place Viala, E. N. S. A., \\ 34060 Montpellier Cedex.
}

\section{SUMMARY}

The influence of aging on the size of the adipocytes of four adipose deposits (perirenal, peristomacal, interscapular and neck) was studied in male New-Zealand rabbits.

At the beginning of growth of adipose tissue, large differences were found in adipocyte size in the various deposits studied. A rapid growth of perirenal fat adipocytes, which ended about I 80 days of age, was observed. The adipocytes of the other deposits showed a lower growth rate, which continues for a longer period. At 300 days of age, differences of adipose size were negligible.

\section{IN'TRODUC'TION}

The evolution of adipocyte size during development of main types of fat deposits in the organism is interesting from a physiological point of view, because it permits investigations on the changes of their metabolic activities as related to cell size evolution (Smith, I97I), (VEzINHET and Nouguis, I973) and helps in defining the growth pattern and changes in cell characteristics of adipocyte populations of each fat deposit.

On the other hand, it is important on the animal husbandry point of view because the distribution and mass of these deposits are important factors in carcass quality evaluation (Vezinhe'T and PRUD'HON, I975; PRUD'HON et al., I970).

The comparative evolution of cellularity, during development of the principal types of adipose tissue, have been studied in the rat (GoldRICK, I967 ; SALANs et al., I972), mouse (HELliman et al., I962 ; LEMONNIER, I972), man (HIRSCH and KNITTLE, 
I970), porcines and bovimes (HOOD, I972; ANDERSON and KAUFFMAN, r973). We have studied, in particular, this aspect of evolution of adipose tissue in the rabbit; species in which the growth parameters are well-known to us.

\section{MATERIAI, AND METHODS}

Twenty-seven male New-Zealand rabbits were allocated into 5 age groups of 30, 50, 70, I80 and 3 oo days old, and were fed, ad libitum, on the same diet. Four fat deposits, of important development in the rabbit, were studied in the perirenal, peristomacal, interscapular and neck regions. It should be noted that in most individuals, the peristomacal fatty tissue was not yet formed at 30 days.

The cell size of these deposits was studied on isolated adipocytes, prepared with RODBELL's technique (1964), $0.5 \mathrm{ml}$ samples of the cell suspension were fixed by a 2 p. Ioo osmium tetroxyde solution in a phosphate buffer $(\mathrm{pH}=7.3)$ at $37^{\circ} \mathrm{C}$ for 24 to 48 hours. Isolated adipocytes fixed by osmium tetroxyde had a spherical shape and the diameter of 250 to 300 cells was measured under a microscope at $\times 200$ to $\times 500$ magnification, varying according to the deposit studied and the age of the subjects. Diameter distribution frequencies stabilized after about zoo measurements.

Cells isolated by collagenase treatment constituted a very representative sample of the fat deposit studied. When comparisons were made in perirenal adipose tissue at the various ages studied, very similar frequency distributions were found for cell diameters obtained from isolated cell samples and from measurements of frozen-cut slices (roo to $200 \mu \mathrm{m}$ thickness) of tissue sample fixed in four per cent formaldehyde. These parallel results have also been confirmed by SMITH et al. (1972) for human adipose tissue.

Mean surface and volume were calculated from the central values of cell diameter distribution classes, as follows :

$$
\text { Mean surface }=\frac{\sum\left(s_{i} \cdot f_{i}\right)}{n} \quad \text { Mean volume }=\frac{\Sigma\left(v_{i} \cdot f_{i}\right)}{n}
$$

where : $s_{i}$ is the surface of the $i^{\text {th }}$ class

$0<i<$ Io

$v_{i}$ is the volume of the $i$ th class

$f_{i}$ is the number of cells in the $i^{\text {th }}$ class

$n$ is the total number of cells measured.

\section{RESULTS AND DISCUSSION}

Table I shows mean data obtained for the five ages studied. Adipocyte size evolution varied with the anatomical site of the deposit. Thus, at 30 days perirenal adipocyte mean volume already reached $37 \mathrm{p}$. I oo of its value at 300 days, while the mean volume of subcutaneous neck deposit adipocytes only attained $6 \mathrm{p}$. Ioo of the 300 days value. These were deposits with the most contrasting characteristics of evolution. The growth of the perirenal adipocyte was the fastest and at 180 days it was practically finished, while it continued slightly after this age in the other fat deposits studied. Adipocyte size in peristomacal and interscapular deposits had a more similar evolution. Differences in the mean diameters of adipocytes in the four deposits studied tended to diminish with age, and became unimportant at 300 days. 
TABLE I

Evolution in relation to age of mean diameter, surface and volume of adipocytes in adipose perivenal, peristomacal, interscapular and neck deposits of the New-Zealand rabbit

\begin{tabular}{|c|c|c|c|c|c|}
\hline $\begin{array}{c}\text { Age } \\
\text { (days) }\end{array}$ & $\begin{array}{l}\text { Number } \\
\text { of } \\
\text { animals }\end{array}$ & Adipose deposit & $\begin{array}{c}\text { Mean diameter }(\mu \mathrm{m}) \\
\text { and } \\
\text { standard deviation }\end{array}$ & $\begin{array}{l}\text { Mean surface } \\
(\mu \mathrm{m})^{2} \cdot 10^{-2}\end{array}$ & $\begin{array}{l}\text { Mean volume } \\
(\mu \mathrm{m})_{3} \cdot 10^{-4}\end{array}$ \\
\hline \multirow{3}{*}{30} & \multirow{3}{*}{5} & Perirenal & $\begin{array}{r}82,88 \\
2,84\end{array}$ & 259,48 & 41,78 \\
\hline & & Interscapular & $\begin{array}{r}60,96 \\
4,27\end{array}$ & 136,46 & 16,84 \\
\hline & & Neck & $\begin{array}{r}36,86 \\
4,54\end{array}$ & 55,01 & 4,52 \\
\hline \multirow{4}{*}{50} & \multirow{4}{*}{5} & Perirenal & $\begin{array}{r}83,54 \\
0,46 \\
\end{array}$ & 234,89 & 36,71 \\
\hline & & Peristomacal & $\begin{array}{r}71,36 \\
1,30\end{array}$ & 173,59 & 25,80 \\
\hline & & Interscapular & $\begin{array}{r}64,50 \\
1,60\end{array}$ & 144,43 & 18,11 \\
\hline & & $\overline{N e c k}$ & $\begin{array}{r}43,36 \\
2,5 / 4\end{array}$ & 73,98 & 7,06 \\
\hline \multirow{4}{*}{70} & \multirow{4}{*}{5} & Perirenal & $\begin{array}{r}97,04 \\
6,70\end{array}$ & 402,79 & 70,47 \\
\hline & & Peristomacal & $\begin{array}{r}89,20 \\
4,17\end{array}$ & 295,36 & 50,99 \\
\hline & & Interscapular & $\begin{array}{r}82,17 \\
5,04\end{array}$ & 237,33 & 37,86 \\
\hline & & Neck & $\begin{array}{r}57,99 \\
3,40\end{array}$ & 123,10 & 13,63 \\
\hline \multirow{4}{*}{180} & \multirow{4}{*}{6} & Perirenal & $\begin{array}{r}123,71 \\
5,44\end{array}$ & 520,71 & 122,88 \\
\hline & & Peristomacal & $\begin{array}{r}114,58 \\
t, 68\end{array}$ & 414,98 & 87,94 \\
\hline & & Interscapular & $\begin{array}{r}116,35 \\
24,29\end{array}$ & 446,74 & 93,07 \\
\hline & & Neck & $\begin{array}{l}95,55 \\
20,52\end{array}$ & 303,66 & 52,41 \\
\hline \multirow{4}{*}{300} & \multirow{4}{*}{6} & Perirenal & $\begin{array}{r}116,00 \\
5,36\end{array}$ & 448,76 & 111,26 \\
\hline & & Peristomacal & $\begin{array}{r}135,22 \\
6,00\end{array}$ & 614,11 & 156,27 \\
\hline & & Interscapular & $\begin{array}{r}127,94 \\
5,30\end{array}$ & 566,91 & 139,06 \\
\hline & & Neck & $\begin{array}{r}102,90 \\
9,20\end{array}$ & 367,20 & 77,38 \\
\hline
\end{tabular}


Furthermore, evolution of the distribution of adipocyte diameters in perirenal and neck regions (fig. I) in relation to age shows a frequency displacement in the neck towards larger diameters with disappearance of small diameter cells. On the other hand, the displacement for perirenal deposits is less obvious ; there is no disappearance of small diameter cells and their frequencies remain almost constant. The dispersion of cell diameters increase with age, and is greater for perirenal fat cells.
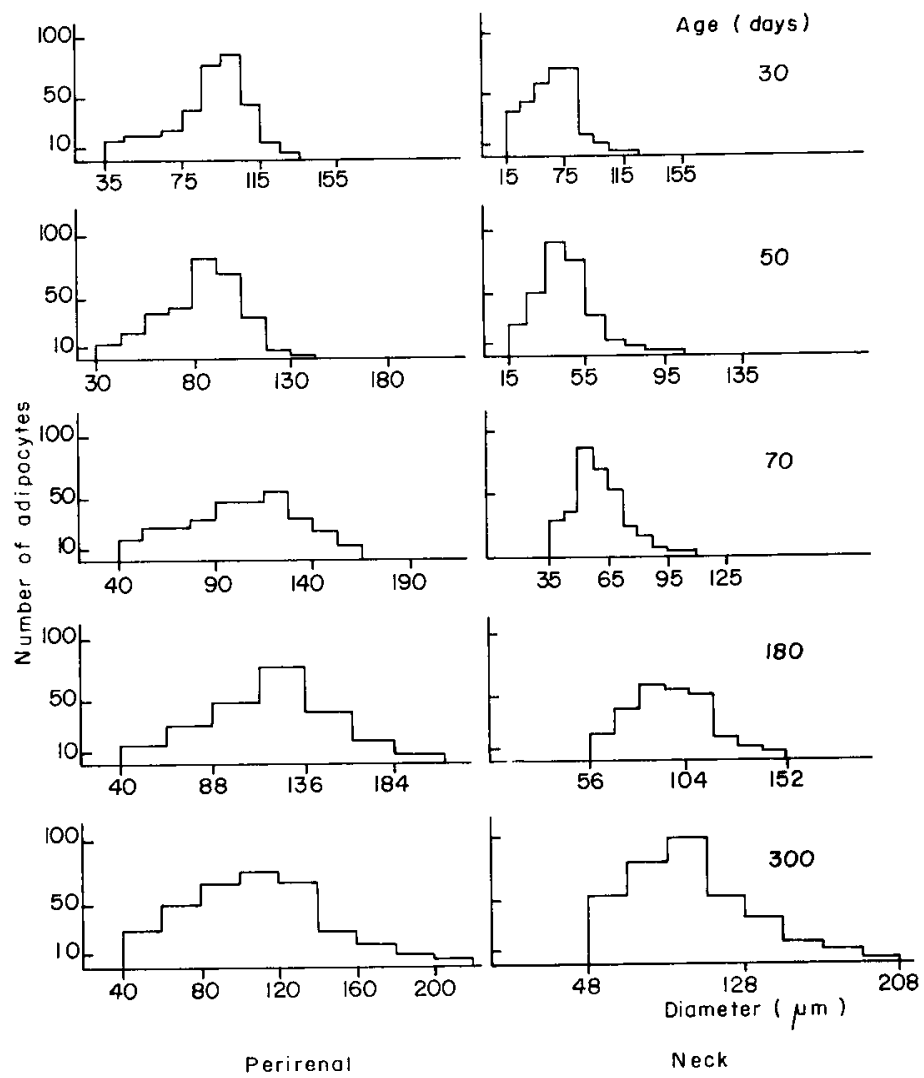

FIG. I. - Evolution with age of adipocyte diameter distribution in perirenal and neck fat deposits

Differences in the temporal evolution of adipocyte diameter distributions in perirenal and neck regions suggest that the growth mechanisms in these two deposits, one deep and the other external, are different. In fact, the neck deposit presents a clear displacement of cell diameters towards higher values, especially at 70 days, and a disappearance of small diameter cells. On the other hand, the perirenal deposit has large diameter adipocytes very early, which hypertrophy little after-wards, and small diameter cells are always present with almost constant frequency.

Thus, the preceding facts suggest that the growth of the neck deposit could occur, after 70 days of age, mainly by adipocyte growth; that of the perirenal deposit could also occur by a cellular growth but moreover by the maintenance of long-term cellular multiplication. 
These differencies in developmental behavior between deep and superficial deposits have been also reported by LEMONNIER (I972). This author, inducing obesity in mouse and rat by fat rich diet, noted that weight increase of perirenal deposit was mostly caused by cellular hyperplasia, while the increase in weight of epididymal and subcutaneous deposits was principally due to cellular hypertrophy. Between the ages of 180 and 300 days, when the growth of adipocytes, of the deposits studied is low, there was always large dispersion in cell size which cannot be explain at present time. The fate of adipocytes after maturation and the possibility of their renewal are not known (VODOVAR et al., I97I).

Intracellular lipid accumulation causes adipocyte volume to increase. Now, results obtained in the laboratory (VEzINHET and Nouguis, 1973) on the metabolic activity of the deposits studied, showed that cells of superficial fat tissue (especially in the neck) had more intense lipolytic activity, up to about 70 days, than deep deposit cells. This probably explains why superficial adipose deposits present smaller adipocytes at the beginning of development than deep fat deposits. It may be that lipogenic activity in these tissues becomes similar at about I8o days. For, at that age, lipolytic activities of different deposits are very much a like, and deviations in adipocyte size noted in the deposits also become low at that time.

On the other hand, a study, done in the laboratory, of weight evolution of fat tissue in growing rabbit (VEZINHET and PRUD'HON, I975) showed a great variability of the weight of fat deposits, at the same age, between individuals (for example, at 70 days perirenal deposit weight had a coefficient of variation greater than $60 \mathrm{p}$. roo). However, variability of the adipocyte mean diameter was much lower (between 5 to I5 p. IOo), which indicates that individual differences in deposit weight are explained principally by a difference in the number of fat cells constituting the deposit. It thus seems that knowledge of the factors responsible for multiplication and adipose cell differenciation is very important in controlling fat tissue development.

There are some differences between species in the cellular characteristics of fat deposits. Thus, for the two superficial deposits studied in rabbit, there is no large variation in adipocyte size at 3 oo days of age, while in man there is large variability in subcutaneous adipocyte size, in relation to the anatomical location of the deposits in which they are found (BJURULF, I959; SALANS et al., I97I). In growing rabbit, mean adipocyte volumes of deep adipose tissues are higher than in superficial adipose tissues. The opposite is observed in the child (BROOK, I97I) and young pig (HooD, I972), where the perirenal deposit presents smaller adipocytes than the subcutaneous deposit.

Reçu pour publication en mars 1975.

\section{ACKNOWLEDGMENTS}

This work was done as a complementary coordinated study, "Reproductive Biology and Development ", of the Délégation générale à la Recherche scientifique et technique, contrat $\mathrm{n}^{\circ} 7 \mathbf{I}-7-3 \mathbf{I} 29$ 


\section{RÉSUMÉ \\ ÉTUDE DE IA CROISSANCE DES ADIPOCYTES \\ DE QUATRE DÉPÔTS ADIPEUX DU LAPIN}

L'évolution, de 30 à 300 jours, de la taille des adipocytes de quatre dépôts adipeux (périrénal, péristomacal, interscapulaire et du cou) a été étudiée chez le Lapin mâle Néo-Zélandais. Au début du développement du tissu adipeux, il y a, entre les divers dépôts, des différences de taille des adipocytes importantes. L'hypertrophie des cellules adipeuses est la plus rapide pour le dépôt périrénal, où elle s'arrête vers I 80 jours, alors qu'elle se prolonge encore faiblement au-delà de cet âge pour les autres dépôts; en sorte que les différences de taille s'atténuent dans le temps pour devenir faibles à 300 jours.

\section{REFERENCES}

Anderson D. B., Kauffman R. G., 1973. Cellular and enzymatic changes in porcine adipose tissue during growth. J. Lipid. Res, 14, 160-168.

BJURUlF P., 1959. Atherosclerosis and body build with special reference to size and number of subcutaneous fat cells. Acta. Med. Scand., suppl., 349, 28-54.

Brook C. G. D., I97r. Composition of human adipose tissue from deep and subcutaneous sites. Brit. J. Nutr., 25, 377-385.

Goldrick R. B., I967. Morphological changes in the adipocyte during fat deposition and mobilisation. Am. J. Physiol., 212, 777-782.

Hellman B. O., Täljedal I. B., Westman S., I962. Morphological characteristics of the epididymal adipose tissue in normal and obese hyperglycemic mice. Acta. Morphol. Neerl. scand., 5, I82+189.

Hirsch J., Knitrle J. L., r97o. Cellularity of obese and non obese human adipose tissue. Fed. Proc., 29, I5I6-I52I.

Hoon R. L., I972. Adipose tissue cellularity and lipogenic activity in porcine and bovine animals. Thèse, Université du Minnesota, p. 298.

LEMONNIER D., r972. Effect of age, sex, and site on the cellularity of the adipose tissue in mice and rats rendered obese by a high-fat diet. J. Clin. Invest., 51, 2907-2915.

Prud'hon M., Vézinhet A., Cantier J., I970. Croissance, qualités bouchères et coût de la production des lapins de chair. Bull. Tech. Inform., 248, 203-212.

RoDbelL M., I964. Metabolism of isolated fat cells. Effects of hormones on glucose metabolism and lipolysis. J. biol. chem., 239, 375-380.

Salans L. B., Horton E. S., Sims A. H., I97I. Experimental obesity in man : cellular character of the adipose tissue. J. Clin. Invest., 50, IOO5-IOII.

Salans L. B., Zarnowski M. J., SEGaL R., 1972. Effect of insulin upon the cellular character of rat adipose tissue. J. Lipid. Res., 13, 6I6-623.

Sмiтн U., г97г. Effect of cell size on lipid synthesis by human adipose tissue in vitro. J. Lipid. Res., 12, $65^{-70}$.

SMtTh U., Sjöström L., Btörntorp P., I972. Comparison of two methods for determining human adipose cell size. J. Lipid Res., 13, 822-824.

Vezinhet A., Nouguk̀s J., I973. In vitro lipolytic activity of porcine growth hormone in the rabbit : effects of location, number and size of adipocytes. The regulation of the adipose tissue mass. Excerpta. Medica. Amsterdam., 77-8I.

Vézinhet A., Prud'hon M., I975. Evolution of various adipose deposits in growing rabbits and lambs Anim. Prod. (sous presse).

Vodovar N., Desnoyers F., François A. C., I97I. Origine et évolution des adipocytes mésentériques du porcelet avant la naissance. J. Micr., 11, 265-284. 